\title{
The adipokine adiponectin has potent anti-fibrotic effects mediated via adenosine monophosphate-activated protein kinase: novel target for fibrosis therapy
}

Feng Fang ${ }^{1}$, Lei Liu ${ }^{2}$, Yang Yang ${ }^{2}$, Zenshiro Tamaki ${ }^{1}$, Jun Wei ${ }^{1}$, Roberta G Marangoni ${ }^{1}$, Swati Bhattacharyya ${ }^{1}$, Ross S Summer ${ }^{3}$, Boping $\mathrm{Ye}^{2}$ and John Varga ${ }^{1^{*}}$

\begin{abstract}
Introduction: Fibrosis in scleroderma is associated with collagen deposition and myofibroblast accumulation. Peroxisome proliferator activated receptor gamma (PPAR- $\gamma$ ), a master regulator of adipogenesis, inhibits profibrotic responses induced by transforming growth factor- $\beta$ (TGF- $\beta$ ), and its expression is impaired in scleroderma. The roles of adiponectin, a PPAR- $\gamma$ regulated pleiotropic adipokine, in regulating the response of fibroblasts and in mediating the effects of PPAR- $\gamma$ are unknown.

Methods: Regulation of fibrotic gene expression and TGF- $\beta$ signaling by adiponectin and adenosine monophosphate protein-activated (AMP) kinase agonists were examined in normal fibroblasts in monolayer cultures and in three-dimensional skin equivalents. AdipoR1/2 expression on skin fibroblasts was determined by real-time quantitative PCR.

Results: Adiponectin, an adipokine directly regulated by PPAR- $\gamma$, acts as a potent anti-fibrotic signal in normal and scleroderma fibroblasts that abrogates the stimulatory effects of diverse fibrotic stimuli and reduces elevated collagen gene expression in scleroderma fibroblasts. Adiponectin responses are mediated via AMP kinase, a fuelsensing cellular enzyme that is necessary and sufficient for down-regulation of fibrotic genes by blocking canonical Smad signaling. Moreover, we demonstrate that endogenous adiponectin accounts, at least in part, for the antifibrotic effects exerted by ligands of PPAR- $\gamma$.

Conclusions: These findings reveal a novel link between cellular energy metabolism and extracellular matrix homeostasis converging on AMP kinase. Since the levels of adiponectin as well as its receptor are impaired in scleroderma patients with progressive fibrosis, the present results suggest a potential role for defective adiponectin expression or function in progressive fibrogenesis in scleroderma and other chronic fibrosing conditions. Restoring the adiponectin signaling axis in fibroblasts might, therefore, represent a novel pharmacological approach to controlling fibrosis.
\end{abstract}

\section{Introduction}

Scleroderma or systemic sclerosis (SSc) is a chronic autoimmune disease associated with fibrosis in multiple organs [1]. Fibrosis in the skin is due to overproduction of collagen and other extracellular matrix (ECM) components

\footnotetext{
* Correspondence: j-varga@northwestern.edu

'Division of Rheumatology, Northwestern University Feinberg School of Medicine, McGaw M230, 240 E Huron Street, Chicago, IL, 60611 USA Full list of author information is available at the end of the article
}

by activated fibroblasts accompanied by progressive loss of subcutaneous adipose tissue [2]. Transforming growth factor- $\beta$ (TGF- $\beta$ ) is a key mediator of fibrosis that initiates and sustains fibroblast activation and myofibroblast differentiation [3]. A variety of cell-autonomous regulatory mechanisms exist to control fibroblast activation and prevent aberrant constitutive fibrogenesis. Peroxisome proliferator-activated receptor gamma (PPAR- $\gamma$ ) is a pleiotropic nuclear receptor implicated in the regulation of 
adipogenesis [4]. Emerging evidence also implicates PPAR$\gamma$ in ECM accumulation and connective tissue homeostasis, and natural and synthetic PPAR- $\gamma$ ligands are potent inhibitors of fibrotic responses [5].

Adiponectin is a multi-functional $30 \mathrm{kD}$ adipokine that regulates insulin sensitivity, energy balance and cellular metabolism [6]. The expression of adiponectin is tightly regulated by PPAR- $\gamma$, and its levels in circulation are decreased in patients with obesity, type 2 diabetes and metabolic syndrome [7]. In contrast, serum levels are raised by PPAR- $\gamma$ agonist treatment in mice and in humans [8]. Significantly, recent studies demonstrate that adiponectin levels are reduced in patients with diffuse cutaneous scleroderma, and are inversely correlated with disease activity, severity and duration [9-12]. These observations point to a potential role for adiponectin in the pathogenesis of scleroderma, but the underlying mechanisms are not currently understood.

The mechanisms of action accounting for the metabolic effects of adiponectin have been extensively characterized $[13,14]$. Biological activity is initiated through adiponectin binding to the cell membrane receptors AdipoR1, AdipoR2 and T-cadherin. The central modulator of the adiponectin signaling cascade is AMP kinase, a key intermediate in cellular energy metabolism [15]. Binding of AMP induces AMP kinase phosphorylation and activation, which both promotes catabolic energy-producing pathways and inhibits anabolic energy-consuming pathways [16]. Whereas the importance of deregulated adiponectin and AMP kinase signaling in metabolic diseases has been long appreciated [17], AMP kinase function in the context of fibrogenesis has not been thoroughly addressed, although emerging evidence suggests that adiponectin might play a significant role. Adiponectin and AMP kinase activation inhibit hepatic stellate cell proliferation and attenuate liver fibrosis [18-20]. In other studies, adiponectin was shown to prevent cardiomyocyte hypertrophy and myocardial fibrosis [21-23].

Fibrosis in scleroderma is associated with impaired PPAR- $\gamma$ expression and activity and reduced adiponectin levels, which may be a direct consequence of the PPAR- $\gamma$ defect $[11,12,24,25]$. In light of these intriguing recent observations, we sought to gain a better understanding of the role of adiponectin in the modulation of collagen synthesis and myofibroblast differentiation in fibroblasts. Results using two-dimensional monolayer cultures and three-dimensional full-thickness human skin equivalents demonstrate that adiponectin potently suppressed the expression of Type I collagen and $\alpha$-smooth muscle actin $(\alpha-S M A)$ in normal and scleroderma fibroblasts, and abrogated the stimulation of these responses elicited by TGF- $\beta$. The inhibitory effects of adiponectin were mediated by activation of AMP kinase. Moreover, genetic deletion of adiponectin in mouse fibroblasts abrogated the inhibition of TGF- $\beta$ signaling elicited by PPAR- $\gamma$ agonists. The expression of adiponectin receptor 1 was selectively reduced in skin biopsies from patients with scleroderma. Taken together, these findings indicate that the adiponectin/AMP kinase pathway may play a previously unrecognized important homeostatic role in ECM regulation, and its defective function contributes to aberrant fibroblast activation in the pathogenesis of fibrosis. The adiponectin signaling pathway, therefore, represents a novel therapeutic target in scleroderma.

\section{Materials and methods \\ Cell culture and reagents}

Primary fibroblast cultures were established by explantation from neonatal foreskin biopsies, or from skin biopsies from healthy adults and scleroderma patients obtained under the protocols approved by the Institutional Review Board at Northwestern University. All donors or their parents/legal guardians provided written informed consent. Mouse skin fibroblasts were established by explant culture from three-week-old adiponectin-null mice and wild-type littermates [26]. Fibroblasts were maintained in (D)MEM) supplemented with $10 \%$ fetal bovine serum (FBS) (Lonza, Basel, Switzerland), $50 \mu \mathrm{g} / \mathrm{ml}$ penicillin, and $50 \mu \mathrm{g} / \mathrm{ml}$ streptomycin in a humidified atmosphere of $5 \% \mathrm{CO}_{2}$ at $37^{\circ} \mathrm{C}$, and studied between passages 2 to 8 [27]. When fibroblasts reached confluence, growth media with $10 \%$ FBS or serum-free media supplemented with $0.1 \%$ BSA were added to the cultures for 24 hours prior to TGF- $\beta 2$ (Peprotech, Rocky Hill, NJ, USA), or full-length adiponectin (Bio Vendor, Karasek, Czech Republic). In selected experiments, the AMP-activated protein kinase (AMPK) inhibitor Compound C (Sigma, St Louis, MO, USA) was added to the culture 60 minutes prior to adiponectin. Toxicity was determined using lactate dehydrogenase (LDH) assays according to the manufacturer's instructions (Biovision, Milpitas, CA, USA).

\section{Three-dimensional full-thickness human skin equivalents}

Normal skin fibroblasts $\left(3 \times 10^{5}\right)$ were suspended in $1.5 \mathrm{ml}$ reconstitution buffer and (D)MEM. Cells were mixed with rat tail type I collagen $(4 \mathrm{mg} / \mathrm{ml}$, BD Biosciences, San Jose, CA, USA) and seeded in 12 -well plates at $37^{\circ} \mathrm{C}$ for 48 hours to solidify the collagen plug. Epidermal keratinocytes $\left(6 \times 10^{6}\right)$ were isolated from foreskin and suspended in E medium supplemented with $5 \mathrm{ng} / \mathrm{ml}$ epidermal growth factor (EGF) and seeded on the collagen plug $[28,29]$. Forty eight hours later, organotypic cultures were placed on a metal grid (BD Biosciences) and maintained at an air-medium interface by feeding with $\mathrm{E}$ medium every other day for five days. Metformin $(1 \mathrm{mM})$ was added to the media for 24 hours followed by TGF- $\beta(5 \mathrm{ng} / \mathrm{ml})$. Following incubation for a further six days, cultures were harvested, RNA was isolated, and tissues were fixed in 
formalin. Paraffin-embedded sections (4 $\mu$ m thickness) were examined by Picrosirius Red staining.

\section{Short interfering RNA-mediated knockdown and adenovirus infection}

Fibroblasts were transfected with target-specific siRNA (Dharmacon, Lafayette, CO, USA) or scrambled control siRNA (10 nM). Twenty-four hours following transfection, fresh media were added to the cultures, and the incubations were continued for a further 24 hours. Knockdown efficiency was evaluated by determining endogenous mRNA levels by real-time qPCR.

\section{RNA isolation and real-time quantitative PCR (qPCR)}

At the end of each experiment, cultures were harvested, RNA was isolated using RNeasy Plus mini kits (Qiagen, Valencia, CA, USA) and examined by real-time quantitative qPCR [30]. Experiments were repeated three times with consistent results. The primers used for $\mathrm{qPCR}$ are shown in Table 1.

\section{Microarray procedures and data analysis}

Expression of AdipoR1/2 mRNA was interrogated in publicly available genome-wide expression scleroderma skin microarray datasets (GEO accession number: GSE9285) [31].

\section{Transient transfection assays}

Fibroblasts at early confluence were transfected with [SBE] 4-luc plasmids harboring four copies of a minimal Smadbinding element using SuperFect Transfection kit (Qiagen) as described [32]. Cultures were incubated in serum-free media containing $0.1 \%$ BSA for 24 hours, followed by TGF- $\beta 2$ for a further 24 hours and harvested. Whole cell lysates were assayed for their luciferase activities using a dual-luciferase reporter assay system (Promega, Madison, WI, USA). In each experiment, Renilla luciferase pRL-TK (Promega) was cotransfected as control for transfection efficiency [33]. Transient transfection experiments were performed in triplicate and repeated at least twice with consistent results.

\section{Confocal immunofluorescence microscopy}

Fibroblasts $\left(1 \times 10^{4}\right.$ cells/well $)$ were seeded onto eight-well Lab-Tek II chamber glass slides (Nalge Nunc International, Naperville, IL, USA) and incubated in serum-free Eagle's minimal essential medium (EMEM) with $0.1 \%$ BSA for 24 hours. Fresh media with adiponectin $(5 \mathrm{ug} / \mathrm{ml})$ were added, and the incubations continued for a further 24 hours. At the end of the experiments, cells were fixed, permeabilized, and incubated with primary antibodies to Type I collagen at 1:500 dilution (Southern Biotech, Birmingham, AL, USA), or to $\alpha$-SMA at 1:200 dilution (Sigma, St Louis, MO, USA). Cells were then washed with PBS and incubated with secondary antibodies at 1:500 dilution (Alexa Fluor 488 and 594, Invitrogen) and viewed under a Nikon C1Si confocal microscope.

\section{Western analysis}

At the end of each experiment, fibroblasts were harvested and whole cell lysates subjected to Western analysis as described [30]. The following antibodies were used: Type I collagen (Southern Biotech), $\alpha$-SMA (Sigma), and GAPDH (Zymed, San Francisco, CA, USA). Bands were visualized using ECL reagents (Pierce, Rockford, IL, USA).

\section{Statistical analysis}

Statistical analysis was performed on Excel (Microsoft, Redmond, WA, USA) using Student t-test or analysis of variance (ANOVA). The results are shown as the means \pm SEM. $P<0.05$ was considered statistically significant.

\section{Results \\ Adiponectin inhibits collagen and alpha-smooth muscle actin gene expression}

To investigate the regulation of fibrotic gene expression by adiponectin, foreskin fibroblasts were maintained in two-dimensional monolayer cultures. At confluence, cultures were incubated in media with an increasing concentration of adiponectin for 24 hours, and changes in gene expression were examined by real-time qPCR, Western analysis and immunocytochemistry. The results demonstrated a dose-dependent inhibition of Col1A1

Table 1 Primers used for real-time qPCR.

\begin{tabular}{lll}
\hline Gene & Primer sequences & Accession number \\
\hline 18S rRNA & olg1, 5'-CCCCATGAACGAGGGAATT-3' olg2, 5'-GGGACTTAATCAACGCAAGCTT-3' \\
GAPDH & olg3, 5'-CATGAGAAGTATGACAACAGCCT-3' olg4, 5'-AGTCCTTCCACGATACCAAAGT-3' \\
ACTA2 (a-SMA) & olg20, 5'-CAGGGCTGTTTCCCATCCAT-3' olg21, 5'-GCCATGTTCTATCGGGTACTTC-3' \\
COL1A1 & olg149, 5'-GCTGGTGTGATGGGATTC-3' olg150, 5'-GGGAACACCTCGCTCT-3' 003286 \\
AdipoR1 & olg396, 5'-TGACTGGCTAAAGGACAACG-3' olg397, 5'-AAAAGAGAAACAGCACGAAACC-3' NM_002046 \\
AdipoR2 & olg400, 5'-CAGCCATTATAGTCTCCCAGTG-3' olg401, 5'-CCGAGATGACATAGTGCAAGG-3' NM_001613 \\
Glut4 & olg404, 5'-ACTGGACGAGCAACTTCATC-3' olg405, 5'-GAGGACCGCAAATAGAAGGA-3' NM_000088
\end{tabular}

Primer sequences were obtained using Primer Express 3.0 software.

Most primer pairs span two exons, except the intronless $18 \mathrm{~S}$ rRNA. Primers were tested by dissociation curve analysis to assure only single amplicon. 
and $\alpha$-SMA gene expression, with a $>60 \%$ reduction at 24 hours (Figure 1 and data not shown). Potent inhibition of Type I collagen and $\alpha$-SMA by adiponectin was confirmed by Western analysis and immunostaining (Figure 1). Comparable results were observed in normal adult dermal fibroblasts (data not shown). Expression of both AdipoR1 and AdipoR2 mRNA in explanted fibroblasts was confirmed by real-time qPCR. Next, we investigated the effect of recombinant adiponectin in scleroderma fibroblasts. Confluent scleroderma fibroblasts ( $n=4$, Table 2$)$ were incubated with adiponectin for 36 hours, and cell lysates were used for Western analysis. Results showed that adiponectin induced an approximately $40 \%$ decrease in collagen gene expression (Figure 1D).

\section{Adiponectin attenuates TGF- $\beta$-induced profibrotic} responses

In light of the fundamental role of TGF- $\beta$ in orchestrating fibrogenesis, it was of interest to evaluate how adiponectin modulated relevant responses elicited by TGF- $\beta$. For this purpose, normal fibroblasts in two-dimensional monolayer cultures were pretreated with adiponectin followed by incubation with TGF- $\beta$ for a further 24 hours. The results of real-time qPCR showed that adiponectin caused a dosedependent attenuation of collagen and $\alpha$-SMA gene expression induced by TGF- $\beta$, with an almost $50 \%$ reduction at $10 \mu \mathrm{g} / \mathrm{ml}$ (Figure 2A). Of note, adiponectin induced an approximately four-fold increase in the levels of the TGF- $\beta$ pseudoreceptor BMP and activin membranebound inhibitor (BAMBI), which negatively regulates TGF- $\beta$ responses. To examine the possible role of endogenous adiponectin in modulating the intensity of TGF- $\beta$ responses, we used an RNAi approach. The results showed that siRNA-mediated effective knockdown of adiponectin in fibroblasts significantly increased the basal levels of Type I collagen and $\alpha$-SMA mRNA and protein (1.5-fold and 1.8-fold, respectively). Moreover, adiponectin-depleted fibroblasts were hypersensitive to TGF- $\beta$ treatment, with significantly enhanced stimulation of collagen and $\alpha$-SMA gene expression compared to fibroblasts transfected with
A
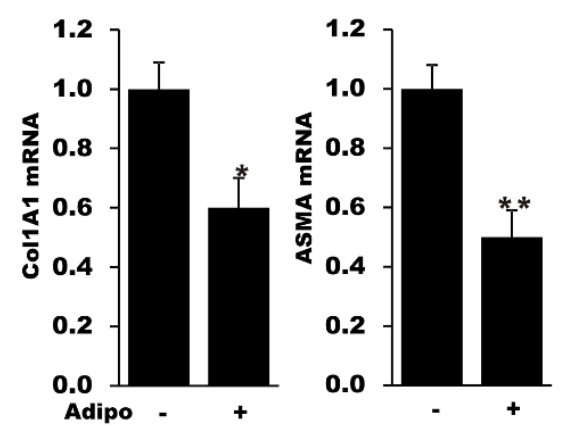

C

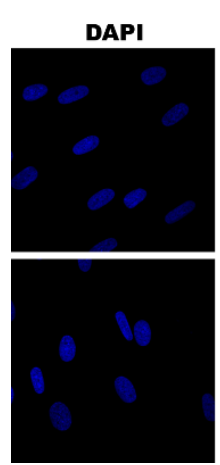

Type I Cgn

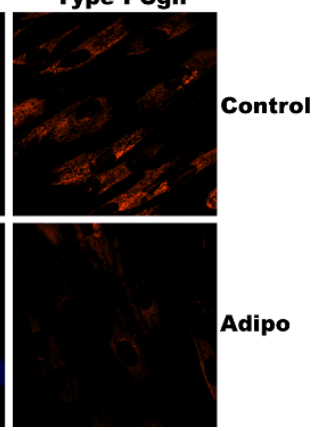

Figure 1 Adiponectin inhibits collagen and alpha-smooth muscle actin gene expression. Confluent control (A-C) or scleroderma (D) dermal fibroblasts were incubated with adiponectin $(5 \mathrm{ug} / \mathrm{ml})$ for 24 to 36 hours. A. Total RNA was subjected to real-time qPCR. The results represent the means \pm SEM of triplicate determinations. ${ }^{*} P<0.05$, ${ }^{*} P<0.01$. B, D. Whole cell lysates were analyzed by Western blot.

Representative autoradiographs. C. Fibroblasts were immunostained with antibodies to Type I collagen (red) or $\alpha$-SMA (green), or stained with DAPI (blue), and examined by confocal microscopy. Representative immunofluorescence photomicrographs. Original magnification $\times 60$. $\alpha$-SMA, $\alpha$-smooth muscle actin; DAPI, 4',6-diamidino-2-phenylindole; SEM, standard error of the mean. 
Table 2 Clinical features of SSc patients.

\begin{tabular}{lllllll}
\hline Patients & Age & Sex & SSc type & Early/Late & Duration (years) & MRSS \\
\hline N900 & 43 & F & & & & \\
N901 & 43 & F & & & & \\
N1003 & 26 & M & & & & 12 \\
N1016 & 35 & F & & & & 19 \\
S902 & 54 & F & ICSSC & Early* & 1 & N/A \\
S903 & 39 & F & dcSSC & Late & 5 & 26 \\
S904 & 33 & F & dcSSC & Late & 9 & 15 \\
S1004 & 27 & F & dcSSC & Late & 10 & 20 \\
S1066 & 21 & M & dcSSC & Early & 2 & 4 \\
S1156 & 48 & F & SSC/PM & Early & 1 & S \\
S1302 & 51 & F & ICSSC & Early & 2 & .
\end{tabular}

*early $=<2$ years from first non-Raynaud symptom at the time of skin biopsy. Fibroblasts from N900-1016 and S902-1004 were used for real-time qPCR analysis. Fibroblasts from S1004-1302 were used for Western blot analysis. MRSS, Modified Rodnan skin score; SSc, systemic sclerosis.

control siRNA, suggesting an inhibitory function for endogenous adiponectin in setting the intensity of TGF- $\beta$ signaling.
Agonists of AMP kinase inhibit fibrotic gene expression and abrogate TGF- $\beta$ responses

In mesenchymal cells, adiponectin induces AMP kinase activity ([34] and data not shown). To investigate the role of AMP kinase in modulating fibrotic gene expression, fibroblasts were incubated with the selective AMP kinase agonists 5-amino-1- $\beta$-D-ribofuranosyl-imidazole4-carboxamide (AICAR) or metformin. The results of real-time qPCR demonstrated a potent dose-dependent inhibition of Col1A 1 and Col1A 2 mRNA expression, with a nearly $90 \%$ reduction at $5 \mathrm{mM}$ of the AMP kinase antagonists (Figure 3). There was no evidence of cellular toxicity even at the highest concentrations of AICAR or metformin tested (data not shown). In addition to collagen, multiple genes implicated in fibrogenesis showed substantial decrease in expression. To establish the specificity of the anti-fibrotic activity of AMP kinase agonists, we examined the expression of the insulin-regulated glucose transporter GLUT4, a target gene positively regulated by AMP kinase [35]. As expected, AICAR induced a substantial increase in
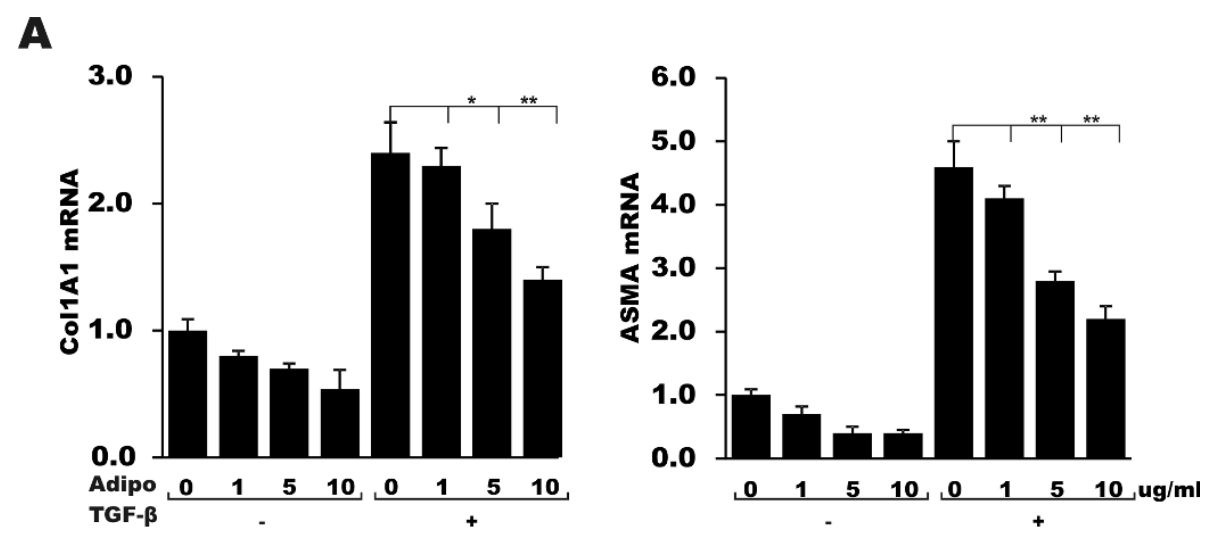

B
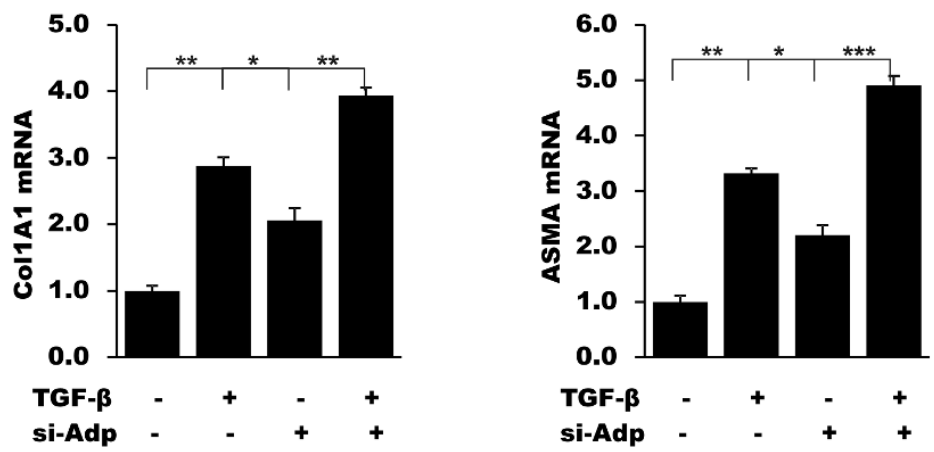

Figure 2 Adiponectin attenuates TGF- $\beta$-induced profibrotic responses. A. Confluent dermal fibroblasts were incubated with or without TGF$\beta(2 \mathrm{ng} / \mathrm{ml})$ in the presence of the indicated concentration of adiponectin for 48 hours. Total RNA was subjected to real-time qPCR. The results represent the means \pm SEM of triplicate determinations. B. Fibroblasts were preincubated with adiponectin-specific siRNA or control siRNA. SEM, standard error of the mean; TGF- $\beta$, transforming growth factor $\beta$ 
A
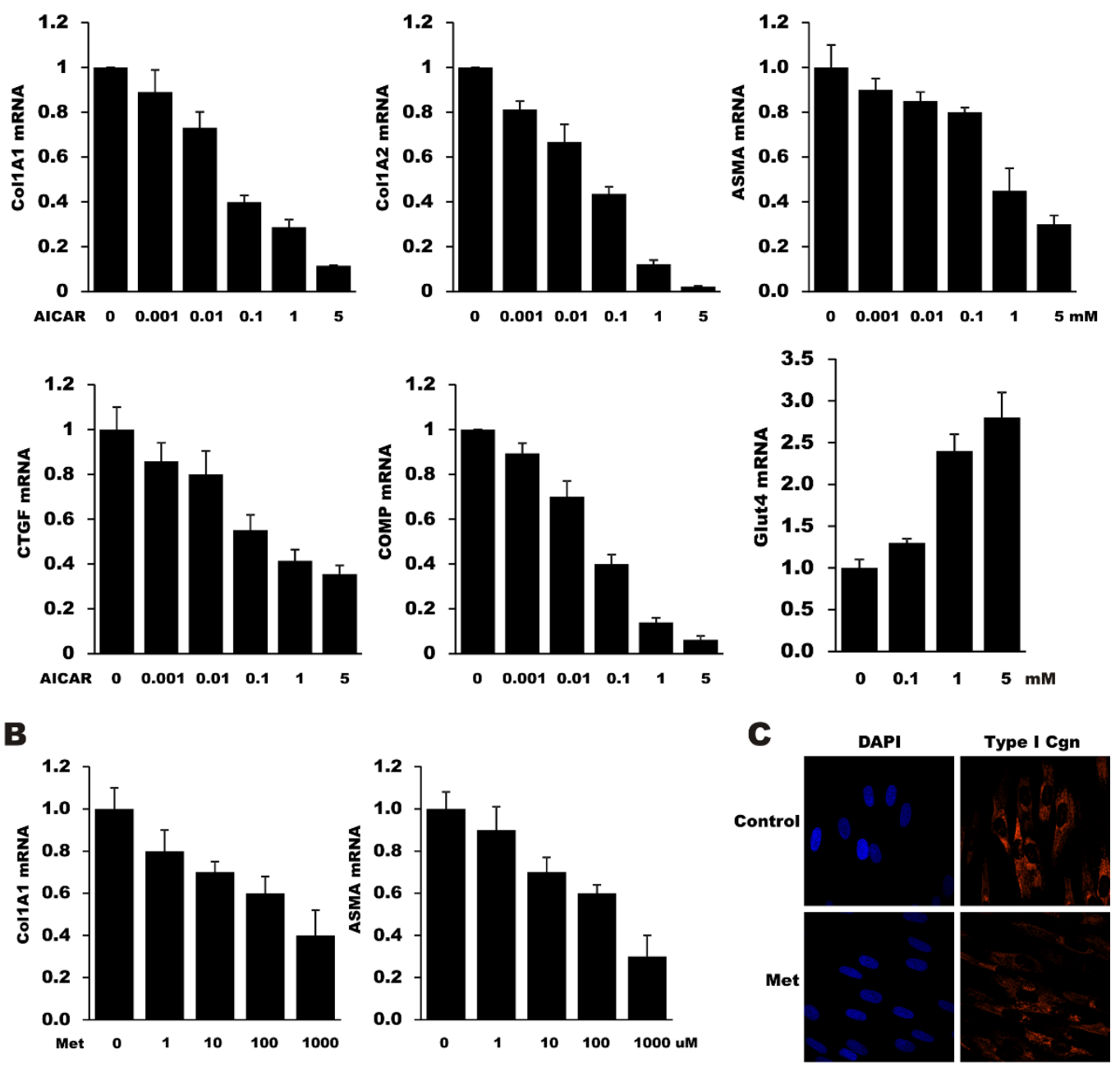

D
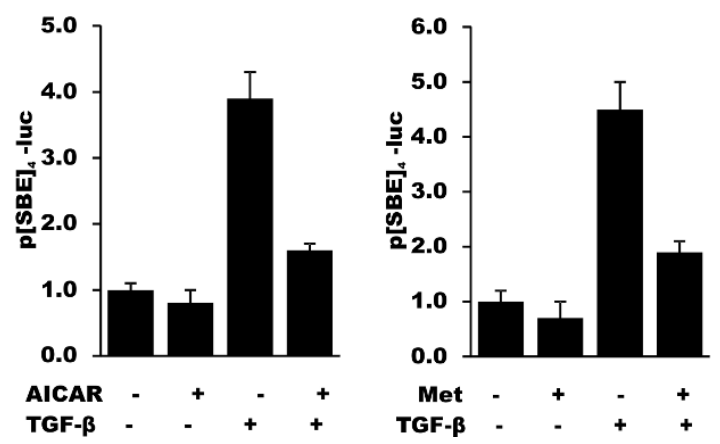

Figure 3 AMP kinase agonists inhibit profibrotic gene expression. Confluent dermal fibroblasts in two-dimensional monolayer cultures were incubated with the indicated concentrations of (A) AICAR or (B) metformin for 24 hours. Total RNA was subjected to real-time qPCR. The results represent the means \pm SEM of triplicate determinations. C. Fibroblasts were immunostained with antibodies to Type I collagen (red), or stained with DAPI (blue). Representative immunofluorescence photomicrographs. Original magnification $\times 60$. D. Fibroblasts transiently transfected with (SBE) 4 -luc were pre-treated with AICAR or metformin (1 mM) for 24 hours, followed by TGF- $\beta$ (10 ng/ml) for 24 hours. Cell lysates were assayed for their luciferase activities. The results represent the means \pm SEM of triplicate determinations. AICAR, 5-amino-1- $\beta$-D-ribofuranosyl-imidazole-4-carboxamide; DAPI, 4',6-diamidino-2-phenylindole; SEM, standard error of the mean; TGF- $\beta$, transforming growth factor- $\beta$. 
GLUT4 mRNA expression. Both AMP kinase agonists potently attenuated the fibrotic responses induced by TGF- $\beta$ (data not shown). To investigate the mechanism, transient transfection assays were performed. The results showed that adiponectin incubation resulted in disruption of canonical Smad signaling, as shown in transient transfection assays with the Smad-responsive minimal promoter $(\mathrm{SBE})_{4}$-luc (Figure 3D).

The organotypic raft culture (ORC) model is a threedimensional full-thickness human skin equivalent that is a powerful approach to studying fibroblast function in the context of fibrogenesis [28]. This full thickness human skin equivalent model allows us to examine fibroblast behavior where the biomechanical forces impacting the fibroblasts are relevant to the physiologically relevant context of skin [28]. The three-dimensional full-thickness skin equivalents were incubated with metformin $(1 \mathrm{mM})$ with or without TGF- $\beta$ ( $5 \mathrm{ng} / \mathrm{ml})$ for six days. Results from real-time qPCR showed that while TGF- $\beta$ induced a substantial increase in fibrotic gene expression, treatment with metformin abrogated the effect (Figure 4A).
Picrosirius Red staining showed that TGF- $\beta$ induced a notable accumulation of strongly birefringent red collagen fibers, indicating highly cross-linked collagen, in the dermal compartment. In contrast, pretreatment of the rafts with metformin prevented collagen maturation, with a predominance of green, less cross-linked collagen fibers (Figure 4B), confirming that metformin abrogated TGF- $\beta$ induced collagen protein accumulation.

To directly examine the role of AMP kinase in mediating the antifibrotic effects of adiponectin, a chemical inhibitor of AMP kinase activity was used [36]. In fibroblasts preincubated with Compound $\mathrm{C}$, a selective and potent AMP kinase inhibitor, the inhibitory effects of adiponectin on TGF- $\beta$-induced collagen and $\alpha$-SMA mRNA and protein were completely abrogated (Figure 5).

\section{Adiponectin mediates the anti-fibrotic effects of PPAR- $\gamma$} ligands

We have shown previously that both pharmacological and endogenous ligands of PPAR- $\gamma$ inhibited collagen gene expression, and abrogated the stimulation of fibrotic
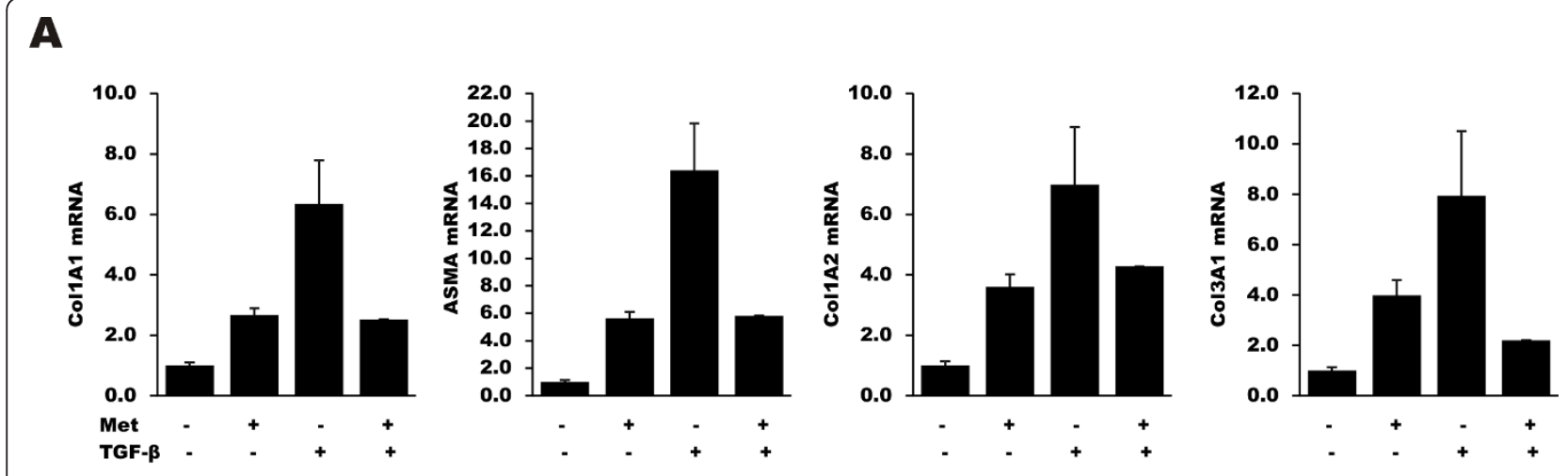

B
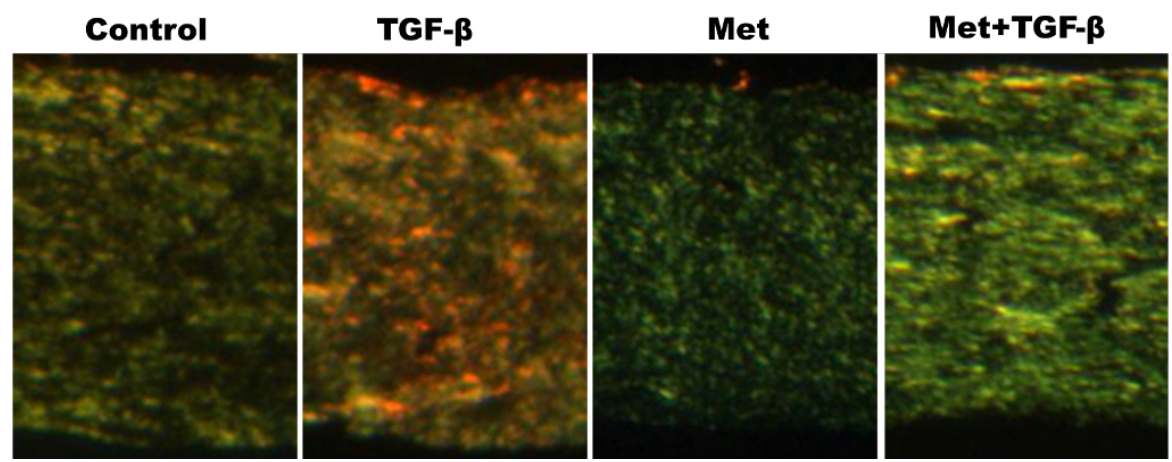

Figure 4 AMP kinase agonists attenuate TGF- $\beta$-induced profibrotic responses in three-dimensional full-thickness human skin equivalents. Fibroblasts embedded in three-dimensional full-thickness skin equivalents were incubated with metformin (1 mM) with or without TGF- $\beta(5 \mathrm{ng} / \mathrm{ml})$ for six days. At the end of the experiments, rafts were harvested. A. Real-time $\mathrm{qPCR}$. The results represent the means \pm SEM of triplicate determinations. B. 4- $\mu \mathrm{m}$ thick paraffin-embedded sections were stained with Picrosirius Red. Mature highly cross-linked collagen fibers in the dermal compartment appear red when visualized under polarized light, whereas less mature collagen fibers containing few cross-links appear yellow/green. Representative images (original magnification $\times 40$ ). SEM, standard error of the mean; TGF- $\beta$, transforming growth factor- $\beta$. 


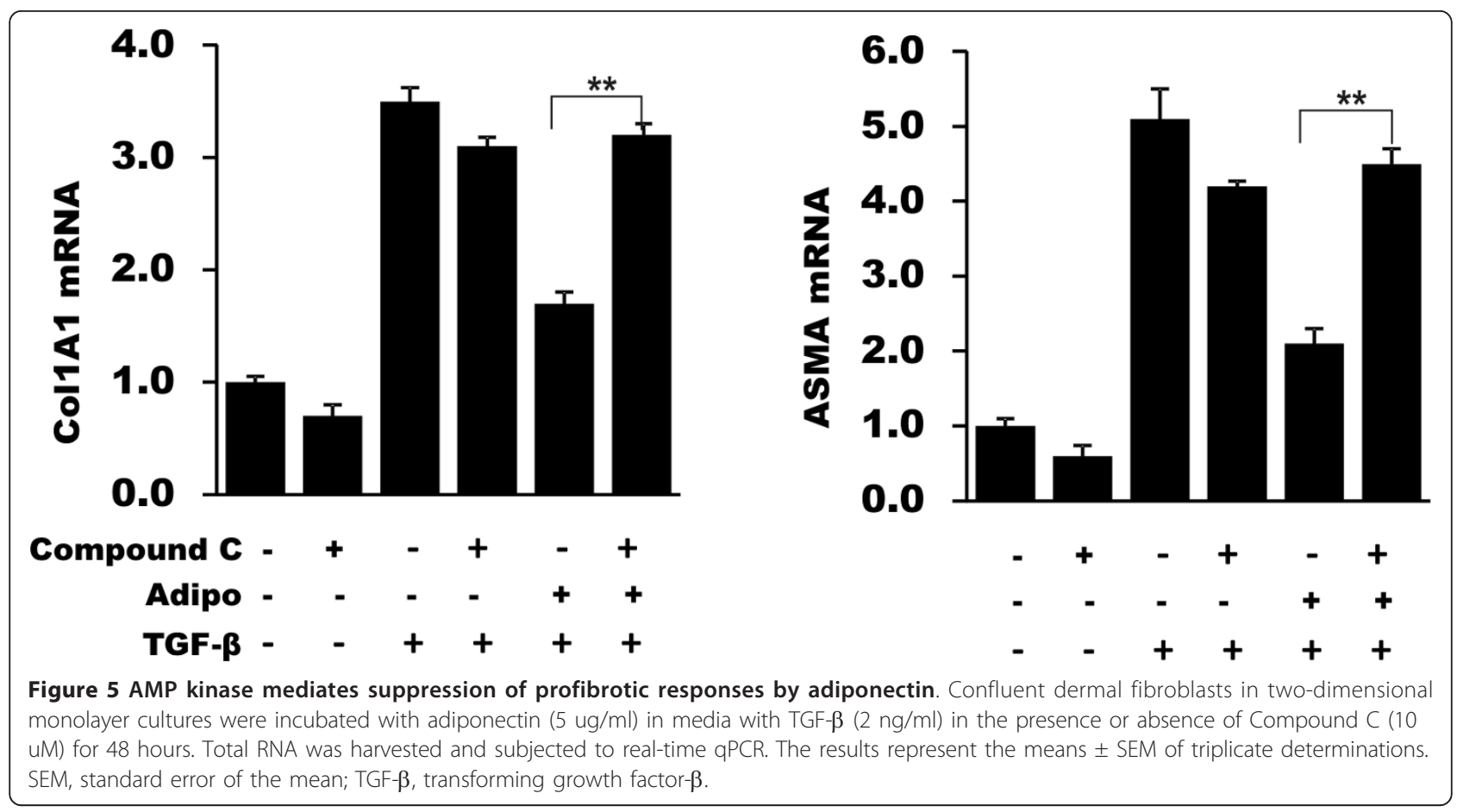

responses elicited by TGF- $\beta$ [37]. Moreover, rosiglitazone, a PPAR- $\gamma$ ligand inhibited the over-expression of fibrotic genes in fibroblasts explanted from scleroderma patients [24]. The anti-fibrotic activities of these ligands were blocked by the irreversible PPAR $-\gamma$ antagonist GW9662, indicating that they were largely PPAR- $\gamma$ dependent [38]. Adiponectin is a direct transcriptional target of PPAR- $\gamma$, and its expression in both adipocytes and fibroblasts is tightly regulated via activated PPAR- $\gamma$ binding to cognate DNA recognition sequences in the adiponectin gene promoter [11,39]. In order to investigate the potential role of endogenous adiponectin in mediating the anti-fibrotic effects of PPAR- $\gamma$ ligands, we examined the effect of prostaglandin $\mathrm{J} 2\left(\mathrm{PGJ}_{2}\right)$ in adiponectin-null mouse skin fibroblasts. Consistent with the results using RNAi, we found that collagen and $\alpha$-SMA gene expression were significantly elevated in both unstimulated and TGF- $\beta$-stimulated fibroblasts lacking adiponectin compared to wild type control fibroblasts, confirming the significant role of cellular adiponectin in modulating the intensity of TGF- $\beta$-induced fibrotic responses (Figure 6). Importantly, while $\mathrm{PGJ}_{2}$ elicited substantial down-regulation of TGF- $\beta$ responses in wild type fibroblasts, as shown previously [25], no significant $\mathrm{PGJ}_{2}$ effect on the stimulatory response was seen in adiponectin-null fibroblasts.

Adiponectin attenuates LPS-induced profibrotic responses We next sought to determine if the anti-fibrotic effects of adiponectin were specific for TGF- $\beta$, or more generalized for other profibrotic stimuli. To this end, fibroblasts were incubated with lipopolysaccharide (LPS), a potent ligand of Toll-like receptor 4 (TLR4). LPS induced a timedependent stimulation of collagen and $\alpha$ SMA gene expression in normal fibroblasts (Figure 7 and data not shown). However, pretreatment of the cultures with adiponectin completely abrogated the stimulatory effects of LPS.

\section{Adiponectin receptor expression in scleroderma}

Adiponectin-induced cellular responses are mediated through activation of the adiponectin receptors AdipoR1 and AdipoR2 [40]. In order to investigate the adiponectin signaling axis in scleroderma, we examined AdipoR expression. Fibroblasts were explanted from skin biopsies from the affected lesional forearm of four patients with scleroderma (Table 2), and age and sex-matched healthy controls $(n=4)$ and grown to confluence, when total RNA was isolated and subjected to real-time qPCR. The results showed approximately $40 \%$ lower levels of AdipoR1 mRNA in scleroderma fibroblasts compared to normal fibroblasts, but the differences were not statistically significant $(P=0.22)$ (Figure 8$)$. AdipoR2 levels were comparable in scleroderma and control fibroblasts.

To evaluate AdipoR1/2 mRNA expression in scleroderma skin, the expression of these genes was interrogated in a publicly available microarray dataset examining gene expression in skin [31]. Biopsies clustering within the diffuse and inflammatory intrinsic subsets [31] showed an approximately $30 \%$ reduction in AdipoR1 $(P<0.05)$, 


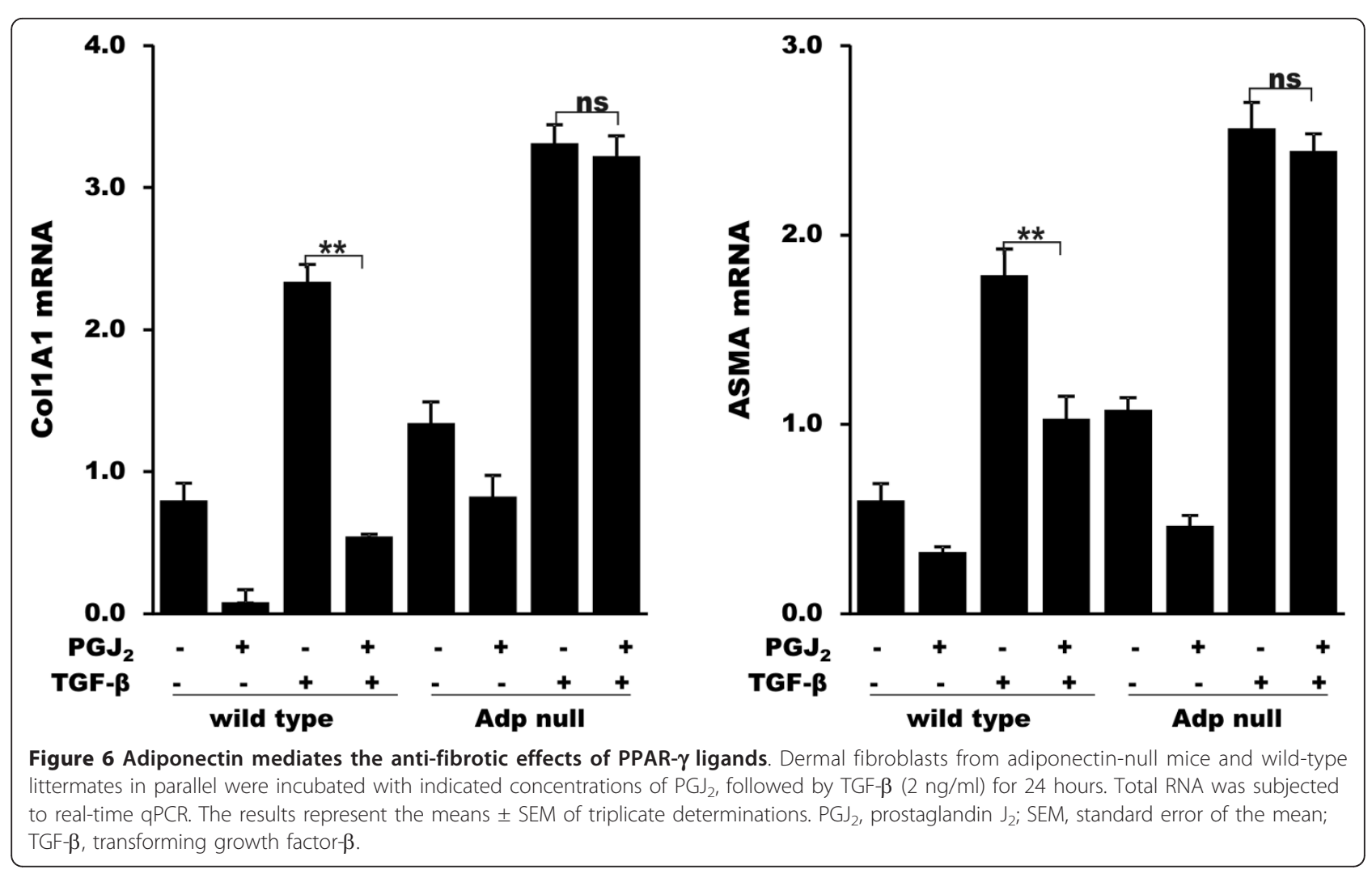

with a slight reduction in AdipoR2 $(P=\mathrm{ns})$ expression compared to biopsies clustering with the normal-like subset (Figure 8B).

\section{Discussion}

Persistence of activated myofibroblasts in response to chronic TGF- $\beta$ signaling underlies the progression of
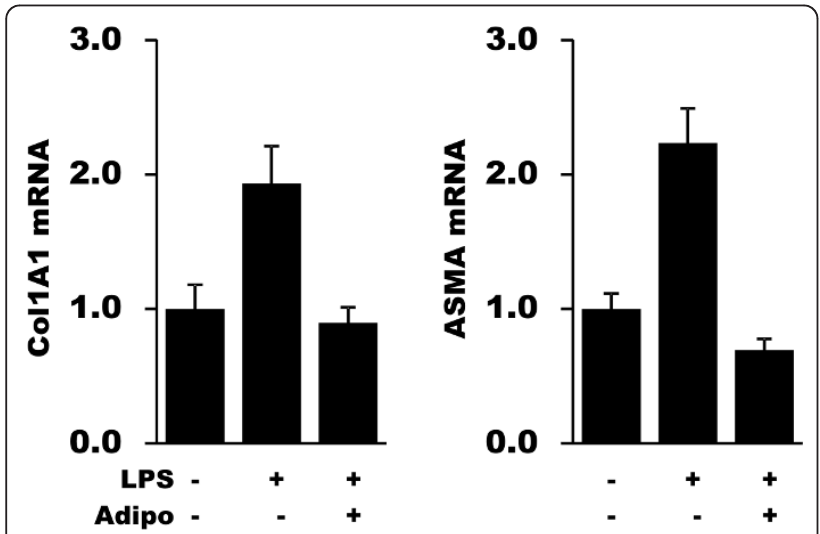

Figure 7 Adiponectin attenuates LPS-induced profibrotic responses. Confluent dermal fibroblasts were incubated with LPS $(1 \mathrm{ug} / \mathrm{ml})$ in the absence or presence of adiponectin $(10 \mathrm{ug} / \mathrm{ml})$ for 24 hours. Total RNA was subjected to real-time GPCR. The results represent the means \pm SEM of triplicate determinations. LPS, lipopolysaccharide; SEM, standard error of the mean. fibrosis in scleroderma [2]. We have demonstrated that PPAR- $\gamma$ activation by endogenous ligands or pharmacological agonists exerts potent inhibitory effects on collagen gene expression and myofibroblast differentiation, and blocks TGF- $\beta$-induced profibrotic responses, in mesenchymal cells in vitro $[37,38]$. Moreover, the PPAR- $\gamma$ ligand rosiglitazone was shown to prevent and attenuate the development of dermal fibrosis in mice [41]. Significantly, recent studies have revealed a marked impairment of PPAR- $\gamma$ expression and activity in skin biopsies from subsets of patients with scleroderma [25]. Moreover, explanted scleroderma fibroblasts showed reduced PPAR- $\gamma$ [24]. We have previously identified a scleroderma subset with impaired PPAR- $\gamma$ signaling that was associated with a strong 'TGF-ß-activated gene signature' in skin biopsies [42]. These scleroderma patients had a rather aggressive form of disease with extensive skin fibrosis. While these findings strongly implicate aberrant PPAR- $\gamma$ function in the persistent fibrosis of scleroderma, the underlying molecular mechanisms remain to be elucidated.

The present studies showed that the PPAR- $\gamma$-regulated adipokine adiponectin caused a marked inhibition of collagen gene expression and myofibroblast differentiation in neonatal and normal adult skin fibroblasts as well as in scleroderma fibroblasts. Significantly, these inhibitory effects occurred at adiponectin concentrations 


\section{$\mathbf{A}$}
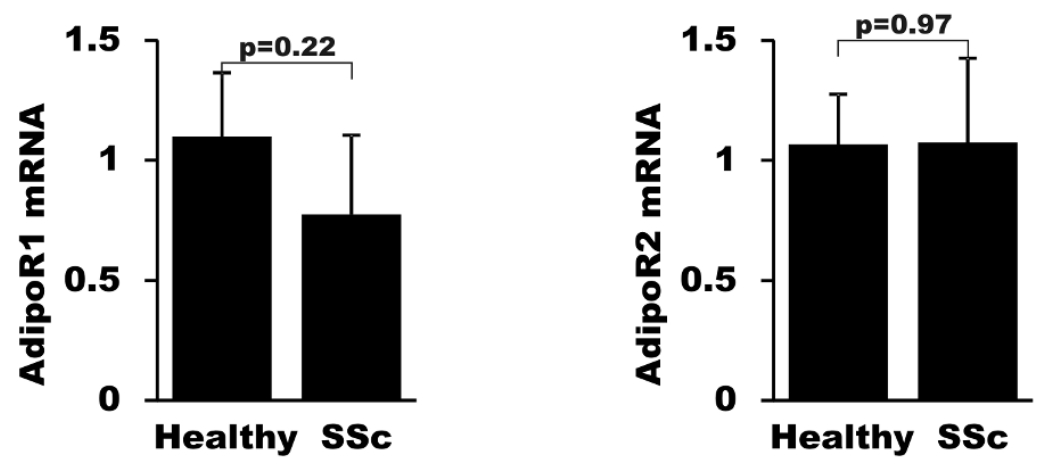

$\mathbf{B}$

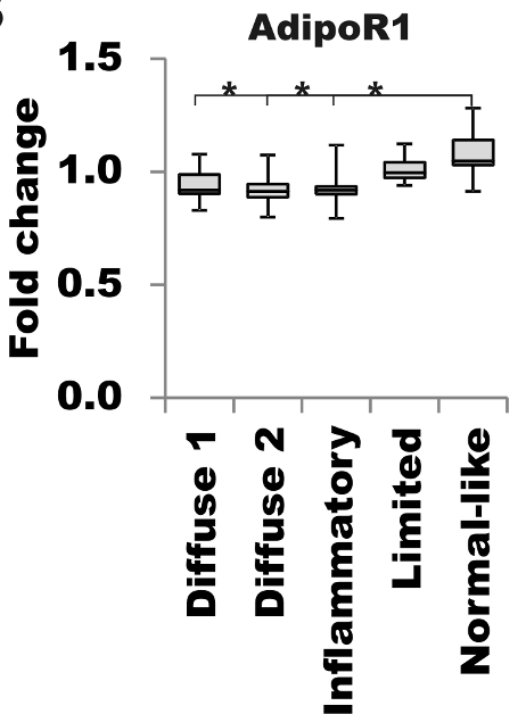

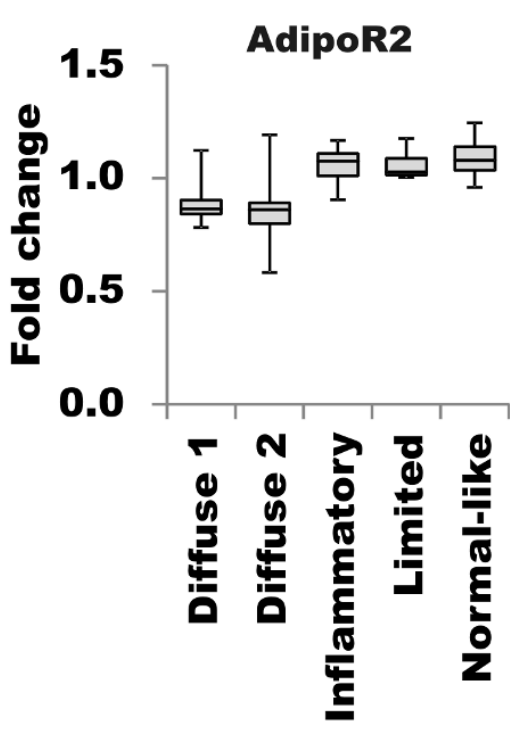

Figure 8 Adiponectin receptor expression in scleroderma. A. Total RNA was isolated from confluent fibroblasts explanted from scleroderma patient $(n=4)$ and healthy controls $(n=4)$, and subjected to real-time $\mathrm{QPCR}$. The results represent the mean \pm SEM of triplicate determinations. B. AdipoR1/2 mRNA expression was interrogated in publicly available genome-wide expression scleroderma skin biopsy microarray datasets (GEO accession number: GSE9285) [31]. Fold-change in mRNA levels was normalized with average expression levels of the samples in the entire cohort. Box plots indicate the range of lower and upper quartiles. ${ }^{*} P<0.05$. SEM, standard error of the mean.

approximating physiological plasma levels (5 to $20 \mu \mathrm{g} / \mathrm{ml}$ ) $[11,43]$. Adiponectin stimulated the expression of BAMBI, an endogenous negative regulator of Smaddependent signaling, while blocking fibrotic responses elicited by TGF- $\beta$, as well as by the TLR4 ligand LPS. While TGF- $\beta$-induced collagen production and myofibroblast transformation are known to be mediated via the canonical Smad signaling pathway [44], the mechanism underlying the fibrotic responses elicited by TLR4 ligands remain incompletely understood. A comparable antagonism between adiponectin and LPS was described in the context of LPS-dependent fibrogenesis in adventitial fibroblasts [45]. The inhibitory effects of adiponectin on fibrotic responses were associated with activation of AMP kinase, a stress-induced metabolic master switch that plays a key role in maintaining energy homeostasis. By detecting and responding to cellular nutrient and energy fluctuations, heterotrimeric AMP kinase promotes catabolic energy-producing pathways to enhance cellular glucose uptake, fatty acid oxidation, and GLUT4 biogenesis [46]. In the present studies, pharmacological AMP kinase agonists mimicked the inhibitory effect of adiponectin on profibrotic gene expression and Smaddependent signaling, while the selective AMP kinase inhibitor Compound $C$ rescued TGF- $\beta$ stimulation of fibrotic genes in the presence of adiponectin. Moreover, transient transfection experiments indicate that AMP kinase attenuation resulted in abrogation of canonical Smaddependent TGF- $\beta$ signaling. While previous studies have highlighted the anti-inflammatory, anti-oxidant and fatty 
acid-regulating activities of AMP kinase [18,47], the present studies reveal important functions for adiponectin in modulating fibrogenesis. The mechanism underlying the anti-fibrotic activities of adiponectin and their significance in health and fibrosis remains to be elucidated.

Adiponectin is an adipocyte-derive pleiotropic hormone with key protective roles in diabetes and atherosclerosis $[17,48,49]$. Sequence-specific recognition of the adiponectin gene promoter PPRE element by activated PPAR- $\gamma$ results in enhanced adiponectin transcription [7]. Recent studies expand the spectrum of the biological activities ascribed to adiponectin, including important roles in regulating inflammation and cancer [50]. Cellular adiponectin responses are mediated via the seven transmembrane domain type 1 and type 2 adiponectin receptors as well as T-cadherin [17]. Obesity is associated with reduced expression of adiponectin receptors in various tissues, contributing to a state of adiponectin resistance [51].

We and others have shown that adiponectin levels are reduced in the serum and lesional skin from patients with scleroderma [10-12]. Adiponectin levels were inversely correlated with the skin score, a measure of fibrotic skin involvement, and scleroderma patients with the most extensive skin fibrosis had the lowest adiponectin levels [11]. Moreover, patients responding to anti-fibrotic treatment with improved skin scores or lung function displayed a time-dependent increase in serum adiponectin levels $[11,12]$.

The important role for adiponectin in negative regulation of connective tissue remodeling suggested by these findings is concordant with recent observations. For instance, adiponectin was shown to down-regulate connective tissue growth factor expression in hepatocytes and hepatic stellate cells, and blocked the stimulatory effect elicited by TGF- $\beta[52,53]$. We have shown that, although adiponectin is primarily produced by adipocytes, its expression is detectable, and strongly up-regulated by PPAR- $\gamma$ ligand in normal dermal fibroblasts [11]. Significantly, both RNAi-mediated adiponectin knockdown in normal fibroblasts and genetic depletion of adiponectin in mouse fibroblasts was associated with increased collagen and $\alpha$-SMA gene expression. Moreover, adiponectindepleted fibroblasts were sensitized to the profibrogenic effects of TGF- $\beta$. These in vitro findings are concordant with in vivo observations that adiponectin-null mice developed exaggerated liver fibrosis when challenged with thioacetamide [54,55]. Moreover, adiponectin-deficient hepatic stellate cells failed to respond to the PPAR- $\gamma$ ligand troglitazone in vitro. Together with these observations, our present results indicate that adiponectin plays an important homeostatic role in negative regulation of collagen deposition and myofibroblast accumulation, and that the anti-fibrotic effects associated with endogenous and pharmacological ligands of PPAR- $\gamma$ are due, at least in part, to activation of the adiponectin/AMP kinase signaling pathway as illustrated in Figure 9. In addition, because scleroderma is associated with impaired PPAR- $\gamma$ activity $[11,24,25]$, reduced adiponectin levels in scleroderma patients are likely to result from impaired PPAR- $\gamma$ activity. Considered in the light of these findings, hypo adiponectin coupled with reduced AdipoR1 expression in scleroderma patients with early diffuse disease suggest that attenuated adiponectin signaling is a risk factor directly contributing to the failure to control aberrant fibrogenic responses, resulting in persistent fibroblast activation and sustained collagen production and myofibroblast differentiation. Indeed, low adiponectin levels and reduced adiponectin receptor expression are associated with accelerated development of liver fibrosis in patients with chronic hepatitis $\mathrm{C}$ infection [56]. Moreover, low adiponectin or AdipoR1 have been shown to predict progression of hepatic steatosis to cirrhosis [57].

The inverse correlation between adiponectin signaling and fibrogenesis in scleroderma in the aforementioned studies suggests a potential role for adiponectin in the pathogenesis of skin fibrosis. We are struck by the parallels between reduced adiponectin and disappearance of fat tissue in liver fibrosis on the one hand, where quiescent fat-strong hepatic stellate cells transition into fibrogenic myofibroblasts with down-regulation of PPAR- $\gamma$, and loss of subcutaneous adipose tissue associated with dermal fibrosis in patients with scleroderma. These parallels raise the intriguing possibility that subcutaneous adipocytes fulfill a role for analogues to that of the hepatic stellate cells of the skin.

\section{Conclusions}

Pharmacological activation of the adiponectin pathway has potent anti-fibrotic effects in normal and scleroderma fibroblasts, and represents an exciting potential

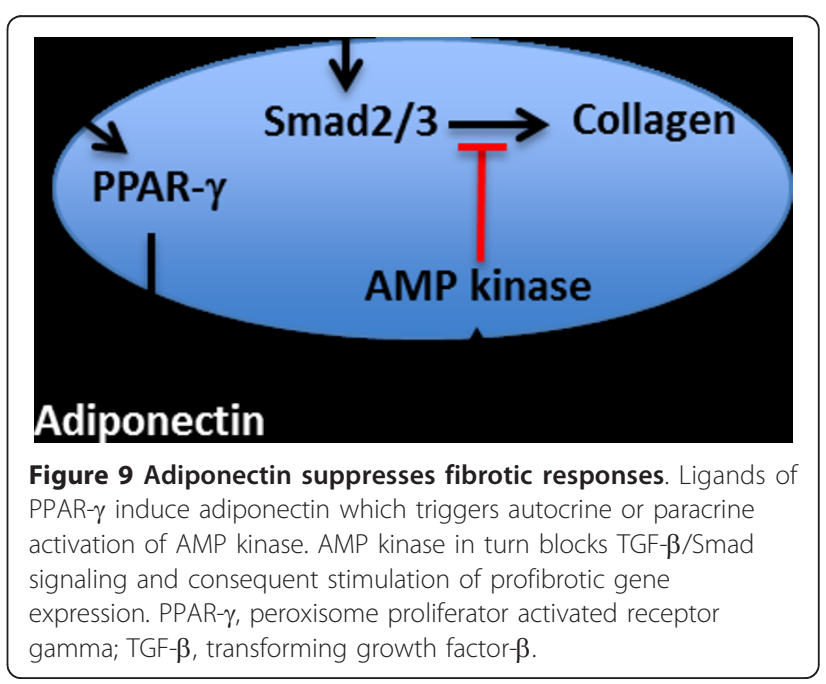


therapeutic approach to the control of dermal fibrosis in scleroderma.

\section{Abbreviations}

AdipoR: adiponectin receptor; AICAR: 5-amino-1- $\beta$-D-ribofuranosyl-imidazole4-carboxamide; a-SMA: a-smooth muscle actin; BSA: bovine serum albumin; (D)MEM: (Dulbecco's) modified Eagle's medium; ECM: extracellular matrix; FBS: fetal bovine serum; EGF: epidermal growth factor; LPS: lipopolysaccharide; $\mathrm{PGJ}_{2}$ : prostaglandin $J_{2} ;$ PPAR- - : peroxisome proliferator activated receptor gamma; qPCR: quantitative polymerase chain reaction; siRNA: small interfering RNA;TGF- $\beta$ : transforming growth factor- $\beta$; TLR4: Tolllike receptor 4

\section{Acknowledgements}

Supported by a grant from the NIH (AR-42309). We are grateful to Junjie Shangguang and Nicholas Fung for technical help and members of the Varga lab for helpful discussions.

\section{Author details}

'Division of Rheumatology, Northwestern University Feinberg School of Medicine, McGaw M230, 240 E Huron Street, Chicago, IL, 60611 USA. ${ }^{2}$ School of Life Science and Technology, China Pharmaceutical University, 24 Tongjiaxiang Street, Nanjing, Jiangsu, 210009 China. ${ }^{3}$ Pulmonary Center, Boston University School of Medicine, 850 Harrison Avenue, Boston, MA, 02118 USA.

\section{Authors' contributions}

FF carried out data analysis and interpretation, and preparation of the manuscript. LL and SB carried out real-time qPCR. YY carried out immunostaining. ZT carried out raft experiments. JW and RGM carried out tissue culture experiments. RS participated in the design of the study. BY participated in coordination and manuscript preparation. JV was involved in study conception and design, manuscript preparation and final approval. All authors read and approved the final manuscript.

\section{Competing interests}

The authors declare that they have no competing interests.

Received: 5 June 2012 Revised: 26 September 2012

Accepted: 19 October 2012 Published: 23 October 2012

\section{References}

1. Rosenbloom J, Castro SV, Jimenez SA: Narrative review: fibrotic diseases: cellular and molecular mechanisms and novel therapies. Ann Intern Med 2010, 152:159-166

2. Bhattacharyya S, Wei J, Varga J: Understanding fibrosis in systemic sclerosis: shifting paradigms, emerging opportunities. Nat Rev Rheumatol 2012, 8:42-54

3. Varga J, Pasche B: Transforming growth factor beta as a therapeutic target in systemic sclerosis. Nat Rev Rheumatol 2009, 5:200-206.

4. Rosen ED, Hsu CH, Wang X, Sakai S, Freeman MW, Gonzalez FJ, Spiegelman BM: C/EBPalpha induces adipogenesis through PPARgamma: a unified pathway. Genes Dev 2002, 16:22-26.

5. Wei J, Bhattacharyya S, Varga J: Peroxisome proliferator-activated receptor gamma: innate protection from excessive fibrogenesis and potential therapeutic target in systemic sclerosis. Curr Opin Rheumatol 2010 22:671-676.

6. Shehzad A, lqbal W, Shehzad O, Lee YS: Adiponectin: regulation of its production and its role in human diseases. Hormones (Athens) 2012, 11:8-20.

7. Iwaki M, Matsuda M, Maeda N, Funahashi T, Matsuzawa Y, Makishima M, Shimomura I: Induction of adiponectin, a fat-derived antidiabetic and antiatherogenic factor, by nuclear receptors. Diabetes 2003, 52:1655-1663.

8. Kusminski CM, Scherer PE: The road from discovery to clinic: adiponectin as a biomarker of metabolic status. Clin Pharmacol Ther 2009, 86:592-595.

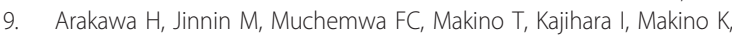
Honda N, Sakai K, Fukushima S, Ihn H: Adiponectin expression is decreased in the involved skin and sera of diffuse cutaneous scleroderma patients. Exp Dermatol 2011, 20:764-766.
10. Tomcik M, Arima K, Hulejova H, Kuklova M, Filkova M, Braun M, Belacek J, Novak M, Becvar R, Vencovsky J, Haluzik M, Gay S, Muller-Ladner U, Distler O, Senolt L: Adiponectin relation to skin changes and dyslipidemia in systemic sclerosis. Cytokine 2012, 58:165-168.

11. Lakota K, Wei J, Carns M, Hinchcliff M, Lee J, Whitfield ML, Sodin Semrl S, Varga J: Levels of adiponectin, a marker for PPAR-gamma activity, correlate with skin fibrosis in systemic sclerosis: potential utility as a biomarker? Arthritis Res Ther 2012, 14:R102.

12. Masui Y, Asano Y, Shibata S, Noda S, Aozasa N, Akamata K, Yamada D, Tamaki Z, Tada Y, Sugaya M, Sato S, Kadono T: Serum adiponectin levels inversely correlate with the activity of progressive skin sclerosis in patients with diffuse cutaneous systemic sclerosis. J Eur Acad Dermatol Venereol 2012, 26:354-360.

13. Shetty S, Kusminski CM, Scherer PE: Adiponectin in health and disease: evaluation of adiponectin-targeted drug development strategies. Trends Pharmacol Sci 2009, 30:234-239.

14. Gnacinska M, Malgorzewicz S, Stojek M, Lysiak-Szydlowska W, Sworczak K: Role of adipokines in complications related to obesity: a review. Adv Med Sci 2009, 54:150-157.

15. Chiarugi $P$, Fiaschi T: Adiponectin in health and diseases: from metabolic syndrome to tissue regeneration. Expert Opin Ther Targets 2010, 14:193-206.

16. Fan W, Downes M, Atkins A, Yu R, Evans RM: Nuclear receptors and AMPK: resetting metabolism. Cold Spring Harb Symp Quant Biol 2012, 76:17-22.

17. Kadowaki T, Yamauchi T: Adiponectin receptor signaling: a new layer to the current model. Cell Metab 2011, 13:123-124

18. Adachi M, Brenner DA: High molecular weight adiponectin inhibits proliferation of hepatic stellate cells via activation of adenosine monophosphate-activated protein kinase. Hepatology 2008, 47:677-685.

19. Caligiuri A, Bertolani C, Guerra CT, Aleffi S, Galastri S, Trappoliere M, Vizzutti F, Gelmini S, Laffi G, Pinzani M, Marra F: Adenosine monophosphate-activated protein kinase modulates the activated phenotype of hepatic stellate cells. Hepatology 2008, 47:668-676.

20. Subramaniam N, Sherman MH, Rao R, Wilson C, Coulter S, Atkins AR, Evans RM, Liddle C, Downes M: Metformin-mediated Bambi expression in hepatic stellate cells induces prosurvival Wnt/beta-catenin signaling. Cancer Prev Res (Phila) 2012, 5:553-561.

21. Shibata R, Ouchi N, Ito M, Kihara S, Shiojima I, Pimentel DR, Kumada M, Sato K, Schiekofer S, Ohashi K, Funahashi T, Colucci WS, Walsh K: Adiponectin-mediated modulation of hypertrophic signals in the heart. Nat Med 2004, 10:1384-1389.

22. Maia-Fernandes T, Roncon-Albuquerque R, Leite-Moreira AF: Cardiovascular actions of adiponectin: pathophysiologic implications. Rev Port Cardiol 2008, 27:1431-1449.

23. Essick EE, Ouchi N, Wilson RM, Ohashi K, Ghobrial J, Shibata R, Pimentel DR, Sam F: Adiponectin mediates cardioprotection in oxidative stressinduced cardiac myocyte remodeling. Am J Physiol Heart Circ Physiol 2011, 301:H984-993.

24. Shi-wen X, Eastwood M, Stratton RJ, Denton CP, Leask A, Abraham DJ: Rosiglitazone alleviates the persistent fibrotic phenotype of lesional skin scleroderma fibroblasts. Rheumatology (Oxford) 2010, 49:259-263.

25. Wei J, Ghosh AK, Sargent JL, Komura K, Wu M, Huang QQ, Jain M, Whitfield ML, Feghali-Bostwick C, Varga J: PPARgamma downregulation by TGF in fibroblast and impaired expression and function in systemic sclerosis: a novel mechanism for progressive fibrogenesis. PLoS One 2010, 5:e13778.

26. Takemura Y, Ouchi N, Shibata R, Aprahamian T, Kirber MT, Summer RS Kihara S, Walsh K: Adiponectin modulates inflammatory reactions via calreticulin receptor-dependent clearance of early apoptotic bodies. J Clin Invest 2007, 117:375-386.

27. Varga J, Brenner D, Phan SH: Fibrosis Research: Methods and Protocols Totowa NJ: Humana Press; 2005

28. Getsios S, Simpson CL, Kojima S, Harmon R, Sheu LJ, Dusek RL, Cornwell M, Green KJ: Desmoglein 1-dependent suppression of EGFR signaling promotes epidermal differentiation and morphogenesis. J Cell Biol 2009, 185:1243-1258

29. Meyers C, Laimins LA: In vitro systems for the study and propagation of human papillomaviruses. Curr Top Microbiol Immunol 1994, 186:199-215.

30. Fang F, Flegler AJ, Du P, Lin S, Clevenger CV: Expression of cyclophilin B is associated with malignant progression and regulation of genes implicated in the pathogenesis of breast cancer. Am J Pathol 2009, 174:297-308. 
31. Milano A, Pendergrass SA, Sargent JL, George LK, McCalmont TH, Connolly MK, Whitfield ML: Molecular subsets in the gene expression signatures of scleroderma skin. PLoS One 2008, 3:e2696.

32. Zawel L, Dai JL, Buckhaults P, Zhou S, Kinzler KW, Vogelstein B, Kern SE: Human Smad3 and Smad4 are sequence-specific transcription activators. Mol Cell 1998, 1:611-617.

33. Fang F, Antico G, Zheng J, Clevenger CV: Quantification of PRL/Stat5 signaling with a novel pGL4-CISH reporter. BMC Biotechnol 2008, 8:11.

34. Fisslthaler $B$, Fleming I: Activation and signaling by the AMP-activated protein kinase in endothelial cells. Circ Res 2009, 105:114-127.

35. Yokoyama U, Patel HH, Lai NC, Aroonsakool N, Roth DM, Insel PA: The cyclic AMP effector Epac integrates pro- and anti-fibrotic signals. Proc Natl Acad Sci USA 2008, 105:6386-6391.

36. Tang CH, Chiu YC, Tan TW, Yang RS, Fu WM: Adiponectin enhances IL-6 production in human synovial fibroblast via an AdipoR1 receptor, AMPK, p38, and NF-kappa B pathway. J Immunol 2007, 179:5483-5492.

37. Ghosh AK, Bhattacharyya S, Lakos G, Chen SJ, Mori Y, Varga J: Disruption of transforming growth factor beta signaling and profibrotic responses in normal skin fibroblasts by peroxisome proliferator-activated receptor gamma. Arthritis Rheum 2004, 50:1305-1318.

38. Ghosh AK, Bhattacharyya S, Wei J, Kim S, Barak Y, Mori Y, Varga J: Peroxisome proliferator-activated receptor-gamma abrogates Smaddependent collagen stimulation by targeting the p300 transcriptional coactivator. FASEB J 2009, 23:2968-2977.

39. Perera RJ, Marcusson EG, Koo S, Kang X, Kim Y, White N, Dean NM: Identification of novel PPARgamma target genes in primary human adipocytes. Gene 2006, 369:90-99.

40. Yamauchi T, Nio Y, Maki T, Kobayashi M, Takazawa T, Iwabu M, OkadaIwabu M, Kawamoto S, Kubota N, Kubota T, Ito Y, Kamon J, Tsuchida A, Kumagai K, Kozono H, Hada Y, Ogata H, Tokuyama K, Tsunoda M, Ide T, Murakami K, Awazawa M, Takamoto I, Froguel P, Hara K, Tobe K, Nagai R, Ueki K, Kadowaki T: Targeted disruption of AdipoR1 and AdipoR2 causes abrogation of adiponectin binding and metabolic actions. Nat Med 2007, 13:332-339.

41. Wu M, Melichian DS, Chang E, Warner-Blankenship M, Ghosh AK, Varga J: Rosiglitazone abrogates bleomycin-induced scleroderma and blocks profibrotic responses through peroxisome proliferator-activated receptor-gamma. Am J Pathol 2009, 174:519-533.

42. Sargent JL, Milano A, Bhattacharyya S, Varga J, Connolly MK, Chang HY, Whitfield ML: A TGFbeta-responsive gene signature is associated with a subset of diffuse scleroderma with increased disease severity. J Invest Dermatol 2010, 130:694-705.

43. Storkson RH, Aamodt R, Vetvik KK, Pietilainen $\mathrm{K}$, Bukholm G, Jonsdottir K, Vollan HS, Sonerud T, Luders T, Jacobsen MB, Bukholm IR: mRNA expression of adipocytokines and glucocorticoid-related genes are associated with downregulation of E-cadherin mRNA in colorectal adenocarcinomas. Int J Colorectal Dis 2012, 27:1021-1027.

44. Chen SJ, Yuan W, Lo S, Trojanowska M, Varga J: Interaction of smad3 with a proximal smad-binding element of the human alpha2(I) procollagen gene promoter required for transcriptional activation by TGF-beta. J Cell Physiol 2000, 183:381-392.

45. Cai XJ, Chen L, Li L, Feng M, Li X, Zhang K, Rong YY, Hu XB, Zhang MX, Zhang $Y$, Zhang $M$ : Adiponectin inhibits lipopolysaccharide-induced adventitial fibroblast migration and transition to myofibroblasts via AdipoR1-AMPK-iNOS pathway. Mol Endocrinol 2010, 24:218-228.

46. Long YC, Zierath JR: AMP-activated protein kinase signaling in metabolic regulation. J Clin Invest 2006, 116:1776-1783.

47. Asterholm IW, Scherer PE: Enhanced metabolic flexibility associated with elevated adiponectin levels. Am J Pathol 2010, 176:1364-1376.

48. Scherer PE, Williams S, Fogliano M, Baldini G, Lodish HF: A novel serum protein similar to C1q, produced exclusively in adipocytes. J Biol Chem 1995, 270:26746-26749.

49. Nakanishi-Minami T, Kishida K, Nakagawa $Y$, Nakatsuji H, Kuroda $Y$, Okauchi Y, Yamasaki K, Nojima Y, Tsujii K, Kumada M, Tachibana K, Nakamura T, Sumitsuji S, Funahashi T, Shimomura I: Carotid intima-media thickness, but not visceral fat area or adiponectin, correlates with intracoronary stenosis detected by multislice computed tomography in people with type 2 diabetes and hypertension. Diabetes Res Clinical Pract 2012, 95:e23-26.

50. Ouchi N, Walsh K: Adiponectin as an anti-inflammatory factor. Clin Chim Acta 2007, 380:24-30
51. Kadowaki T, Yamauchi T, Kubota N, Hara K, Ueki K, Tobe K: Adiponectin and adiponectin receptors in insulin resistance, diabetes, and the metabolic syndrome. J Clin Invest 2006, 116:1784-1792.

52. Walter R, Wanninger J, Bauer S, Eisinger K, Neumeier M, Weiss TS, Amann T, Hellerbrand C, Schaffler A, Scholmerich J, Buechler C: Adiponectin reduces connective tissue growth factor in human hepatocytes which is already induced in non-fibrotic non-alcoholic steatohepatitis. Exp Mol Pathol 2011, 91:740-744.

53. Kim EK, Lim S, Park JM, Seo JK, Kim JH, Kim KT, Ryu SH, Suh PG: Human mesenchymal stem cell differentiation to the osteogenic or adipogenic lineage is regulated by AMP-activated protein kinase. J Cell Physio/ 2012, 227:1680-1687.

54. Olsen AL, Bloomer SA, Chan EP, Gaca MD, Georges PC, Sackey B, Uemura M, Janmey PA, Wells RG: Hepatic stellate cells require a stiff environment for myofibroblastic differentiation. Am J Physiol Gastrointest Liver Physiol 2011, 301:G110-118.

55. Shafiei MS, Shetty S, Scherer PE, Rockey DC: Adiponectin regulation of stellate cell activation via PPARgamma-dependent and -independent mechanisms. Am J Pathol 2011, 178:2690-2699.

56. Corbetta S, Redaelli A, Pozzi M, Bovo G, Ratti L, Redaelli E, Pellegrini C, BeckPeccoz P, Spada A: Fibrosis is associated with adiponectin resistance in chronic hepatitis C virus infection. Eur J Clin Invest 2011, 41:898-905.

57. Targher G, Bertolini L, Rodella S, Zoppini G, Scala L, Zenari L, Falezza G: Associations between plasma adiponectin concentrations and liver histology in patients with nonalcoholic fatty liver disease. Clin Endocrinol 2006, 64:679-683.

doi:10.1186/ar4070

Cite this article as: Fang et al:: The adipokine adiponectin has potent anti-fibrotic effects mediated via adenosine monophosphate-activated protein kinase: novel target for fibrosis therapy. Arthritis Research \& Therapy 2012 14:R229.

\section{Submit your next manuscript to BioMed Central and take full advantage of:}

- Convenient online submission

- Thorough peer review

- No space constraints or color figure charges

- Immediate publication on acceptance

- Inclusion in PubMed, CAS, Scopus and Google Scholar

- Research which is freely available for redistribution

Submit your manuscript at www.biomedcentral.com/submit
C Biomed Central 